\title{
Small and Medium Enterprises (SMEs) with SWOT Analysis Method
}

\author{
Mohamad Rakhmansyah ${ }^{1, *}$, Tri Wahyuningsih ${ }^{2}$, Abdullah Dwi Srenggini ${ }^{3}$ and I Ketut Gunawan ${ }^{4}$ \\ Magister Teknik Informatika, Universitas Raharja, Tangerang, Banten, Indonesia \\ * corresponding author
}

(Received: October 6, 2021; Revised: November 29, 2021; Accepted: January 21, 2022; Available online: September 1, 2022)

\begin{abstract}
This study aims to determine the strengths, weaknesses, opportunities and threats to SMEs in utilizing social media as a marketing tool and to find out the most effective marketing strategies to run in order to increase sales. The method used is SWOT analysis, and in data processing using excel. In collecting data using a questionnaire method distributed in the January 2021 period with a total of 226 respondents. The results obtained by SMEs in utilizing social media as marketing are in quadrant I, which means that the strategy used is a growth strategy, namely the SO strategy which is a strategy that uses strengths to take advantage of opportunities that exist in SMEs. Its implementation is to increase the intensity of promotions, maintain product and service quality, maintain and increase customer trust, be communicative to customers.
\end{abstract}

Keywords: SWOT Analysis, Social Media, Marketing Strategy

\section{Introduction}

Social media is becoming a trend nowadays. Social media, which initially functioned as a community liaison, has evolved into a means of doing business for business people. With innovations that continue to grow, the use of social media is no longer a means for self-expression. But it is also used as a place to find and create business opportunities. Social media can be used by entrepreneurs in increasing customer enthusiasm and cooperation, researching markets, promotional media, flexibility in accessing information, connecting with customers and getting a broad business network. Marketing through social media will affect external factors that affect consumer perceptions of a product, which will then affect consumer buying interest [1]. Gunawan and Huarng [2] suggest that social interaction and perceived risk through social media affect consumer buying interest. Using social media with the intention of marketing their products or services, providing certain information to consumers and promoting the products they produce. Social media is used as a marketing communication tool to increase consumer awareness of the product, improve product image, and end up increasing sales [3]. Promotions carried out by SME actors have also experienced a shift, where many SMEs have switched from promotion through print and electronic media to promotion through the internet, one of which is social media. Social media such as Facebook, Twitter, Instagram, Whatsapp and YouTube are now used as promotional media because social media has become a platform that consumers often use when spending their time online. So, social media is the right place to promote products to consumers. Social media also allows market participants to communicate with fellow producers, customers, and/or potential customers. Social media gives identity to the brand or brands being marketed and helps in spreading the message in a relaxed and communicative way.

Globalization and free markets are a challenge for Small and Medium Enterprises (SMEs) to continue to survive. The rapid flow of information and increasingly free competition have increased consumer and customer awareness of the large selection of goods and services to choose from. If SMEs do not immediately fix themselves, they will be 
threatened with losing competition and going out of business. For this reason, SMEs need to improve themselves and build long-term relationships with consumers and customers [4][5].

Based on the above background, this research focuses on discussing the existing problems. The problems that will be taken are only those related to the analysis of the use of social media as a marketing tool. In solving existing problems, this research will use an analytical method, namely SWOT analysis (Strength, Weakness, Opportunity, and Threat). SWOT analysis helps researchers in completing this research based on the problems to be studied. This study aims to determine the strengths, weaknesses, opportunities and threats to SMEs in utilizing social media as a marketing tool and to find out the most effective marketing strategies to run in order to increase sales.

\section{Methodology}

SWOT analysis is the identification of various factors systematically to formulate the strategy of an organization[6]. SWOT analysis (SWOT analysis) includes efforts to identify the strengths, weaknesses, opportunities, and threats that determine the company's performance. External information regarding opportunities and threats can be obtained from many sources, including customers, government documents, suppliers, banking circles, partners in other companies [7]. Many companies use the services of scanning agencies to obtain newspaper clippings, research on the internet, and analyze company decision making trends. These internal factors include all kinds of functional management: marketing, finance, operations, human resources, research and development, management information systems and corporate culture[7]. The function of the SWOT analysis is to analyze the strengths, weaknesses and competitive advantages of the company/business which is carried out through an analysis of the company's internal conditions, as well as an analysis of the opportunities and threats faced by the company which is carried out through an analysis of the company's external conditions. SWOT analysis compares external opportunities and threats with internal strengths and weaknesses [8].

Social media is defined as a web-based service that allows each individual to build social relationships through cyberspace such as building a profile about himself, showing one's connections, and showing what relationships exist between one owner and another account owner [9]. As a networking site, social media has an important role in marketing. This is because social media can play a communication role. Communication is an effort to make all marketing activities or company promotions that can produce a consistent image or image for the company [10]. At a basic level, communication can inform and make potential consumers aware of the existence of the product being offered [11].

Strategy is a tool to achieve goals where the main goal is so that the organization can see objectively internal and external conditions, so that it can anticipate changes in the external environment [6]. Marketing strategy is a comprehensive, integrated and unified plan in the field of marketing that provides guidance on the activities to be carried out to achieve the marketing objectives of a company [12]. Meanwhile, according to Fandy at al (2012) stated that the marketing strategy is a plan to be followed by marketing managers, this action plan is based on an analysis of the situation and company goals and is a way to achieve these goals [13].

Research on the SWOT analysis method in the use of social media as a marketing tool has been carried out by many researchers. But in general, previous researchers discussed snacks, cosmetics, hotels, tourism, while the research we made was about analytical methods in the use of social media as a means of marketing small and medium businesses.

This study uses the SWOT analysis method, in data processing using excel. In collecting data using a questionnaire method distributed in the January 2021 period. By distributing questionnaires via google form with respondents, small and medium entrepreneurs who carry out their business activities using social media. Respondents amounted to 
226 respondents consisting of 80 male respondents and 146 female respondents. With the age of respondents under 30 years of 131 respondents, and the age of respondents above 31 years of 95 respondents.

The SWOT analysis steps carried out are as follows:

1) Determining Internal Factors:

- Determine the internal factors that are the strengths and weaknesses of SMEs

- Giving weight to each of these factors on a scale ranging from 1.0 (most important) to 0.0 (not important) based on the influence of these factors on the company's strategic position (all these weights must not exceed the total score of 1.00).

- Calculating the rating for each factor by giving a scale ranging from 5 (outstanding) to 1 (poor), based on the influence of positive factors (all variables that fall into the power category) are given values ranging from +1 to +5 (very good). )

- Calculating the weight score, each filled with the result of multiplying the weight with the rating

2) Determine external factors:

- Determine the external factors that become opportunities and threats for SMEs

- Giving weight to each of these factors on a scale ranging from 1.0 (most important) to 0.0 (not important) based on the influence of these factors on the company's strategic position (all these weights must not exceed the total score of 1.00).

- Calculates the rating for each factor by giving a scale ranging from 5 (outstanding) to 1 (poor). The rating value for the opportunity factor is positive (a bigger opportunity is given a +5 rating, but if the opportunity is small, it is given a +1 rating). Giving a threat rating value is the opposite. For example, if the threat value is very large, the rating is +1 . Conversely, if the threat is low the rating is +5 .

- Calculating the weight score, each filled with the result of multiplying the weight with the rating.

3) Make a Cartesian diagram

4) Create a quantitative strategy combination table

\section{Result and Discussion}

In this study using SWOT analysis to analyze the data that has been obtained. The analysis in this study includes an analysis of internal and external factors that have an influence in formulating strategies for small and medium-sized businesses in utilizing the internet as a marketing medium. Internal environmental analysis uses the IFAS (Internal Factor Analysis Summary) table as shown in table 1.

Table. 1. IFAS SME Matrix

\begin{tabular}{|c|l|c|c|c|}
\hline No & \multicolumn{1}{|c|}{ Strength } & Weight & Rating & Score Weight \\
\hline 1 & Wide reach & 0.0776 & 4.257 & 0.3303 \\
\hline 2 & Unlimited time for promotion & 0.0765 & 4.195 & 0.3207 \\
\hline 3 & Cheap promotional media & 0.0753 & 4.133 & 0.3113 \\
\hline 4 & Increasing internet users & 0.0801 & 4.394 & 0.3519 \\
\hline 5 & Facilitate free market & 0.0768 & 4.212 & 0.3234 \\
\hline
\end{tabular}




\begin{tabular}{|r|l|c|c|c|}
\hline 6 & Increase high buying and selling & 0.0746 & 4.093 & 0.3053 \\
\hline 7 & Speed up marketing & 0.0779 & 4.274 & 0.3330 \\
\hline & Sub Total & $\mathbf{0 . 5 3 8 8}$ & & $\mathbf{2 . 2 7 6 0}$ \\
\hline No & \multicolumn{1}{|c|}{ Strength } & Weight & Rating & Score Weight \\
\hline & $\begin{array}{l}\text { Requires good and relevant videos, photos and } \\
\text { narration }\end{array}$ & 0.0734 & 4.0265 & 0.2955 \\
\hline 2 & Competition is quite tight & 0.0740 & 4.0619 & 0.3007 \\
\hline 3 & Lack of trust from customers & 0.0619 & 3.3982 & 0.2105 \\
\hline 4 & Need proof of customer testimonials & 0.0743 & 4.0752 & 0.3027 \\
\hline 5 & Must always update 24 hours & 0.0612 & 3.3584 & 0.2056 \\
\hline 6 & There is no item claim forum & 0.0574 & 3.1504 & 0.1809 \\
\hline 7 & Lack of socialization and education & 0.0590 & 3.2345 & 0.1907 \\
\hline & Sub Total & $\mathbf{0 . 4 6 1 2}$ & & $\mathbf{1 . 6 8 6 6}$ \\
\hline & Total & $\mathbf{1 . 0 0 0 0}$ & & $\mathbf{3 . 9 6 2 6}$ \\
\hline
\end{tabular}

Based on table 1, it can be seen that the power factor that has the highest score is internet users who are increasing with a weighted score of 0.3519. These factors are a strength for SMEs for business continuity and also for business development in the future. The IFAS matrix also shows the various weaknesses that SMEs have. The highest score for the weakness factor is that there needs to be evidence of customer testimonials with a weighted score of 0.3027. This weakness can be an obstacle for SMEs in developing their business. The results of the IFAS matrix analysis on SMEs which include all internal factors (strengths and weaknesses) are in the form of a total score of 3.9626 which means that SMEs have strong strengths and can be utilized for business continuity. External environmental analysis uses the EFAS (External Factor Analysis Summary) table as shown in table 2:

Table. 2. EFAS SME Matrix

\begin{tabular}{|c|l|c|c|c|}
\hline No & \multicolumn{1}{|c|}{ Strength } & Weight & Rating & Score Weight \\
\hline 1 & Products are easier to go viral and famous & 0.0767 & 4.0929 & 0.3139 \\
\hline 2 & $\begin{array}{l}\text { With product reviews, you can improve service } \\
\text { and product quality }\end{array}$ & 0.0798 & 4.2566 & 0.3395 \\
\hline & $\begin{array}{l}\text { Doing business online is easier because it } \\
\text { doesn't require e-commerce }\end{array}$ & 0.0700 & 3.7345 & 0.2614 \\
\hline 4 & $\begin{array}{l}\text { Free sales because they are not tied to other } \\
\text { agencies }\end{array}$ & 0.0729 & 3.8894 & 0.2835 \\
\hline 5 & Easily verified when working with superior & 0.0726 & 3.8761 & 0.2815 \\
\hline
\end{tabular}




\begin{tabular}{|c|l|c|c|c|}
\hline \multicolumn{2}{|l|}{ products } & & & \\
\hline 6 & Join with other businesses (endorsement) & 0.0726 & 3.8761 & 0.2815 \\
\hline 7 & Increase customer trust & 0.0745 & 3.9735 & 0.2959 \\
\hline & Sub Total & $\mathbf{0 . 5 1 9 1}$ & & $\mathbf{2 . 0 5 7 3}$ \\
\hline No & \multicolumn{1}{|c|}{ Strength } & Weight & Rating & Score Weight \\
\hline 1 & Products become easy to imitate (duplicate) & 0.0721 & 3.8451 & 0.2771 \\
\hline 2 & Competitive price & 0.0724 & 3.8628 & 0.2796 \\
\hline 3 & Lots of scams & 0.0681 & 3.6327 & 0.2473 \\
\hline 4 & Product quality does not meet expectations & 0.0662 & 3.5310 & 0.2336 \\
\hline 5 & There is a marketplace & 0.0715 & 3.8142 & 0.2726 \\
\hline 6 & Easy to hijack & 0.0672 & 3.5841 & 0.2407 \\
\hline 7 & There is no guarantee of compensation & 0.0636 & 3.3938 & 0.2158 \\
\hline & Sub Total & $\mathbf{0 . 4 8 0 9}$ & & $\mathbf{1 . 7 6 6 8}$ \\
\hline & Total & $\mathbf{1 . 0 0 0 0}$ & & $\mathbf{3 . 8 2 4 1}$ \\
\hline
\end{tabular}

Based on table 2, it can be seen that the main factor that has the highest opportunity weight score is the existence of a product review, which can improve service and product quality, which has a weight score of 0.3395. The EFAS matrix also shows the main threat factor for SMEs, namely competitive prices with a weight of 0.2796 . This is because many SMEs market their products using social media, this means that the level of price competition is very tight which can affect the sustainability of SMEs in using social media as a marketing tool. The results of the EFAS matrix analysis on SMEs in utilizing social media as a marketing tool that includes all external factors (opportunities and threats) in the form of a total score of 3.8241 which means that SMEs have strong enough opportunities and threats so that SMEs are expected to continue to develop their business in order to remain competitive. well.

Based on table 1 of the IFAS SME Matrix, the results show that the score for the strength factor is 2.2760 and the score for the weakness factor is 1.6866. Meanwhile, based on table 2 of the SME EFAS Matrix, the results show that the score for the opportunity factor is 2.0573 and the score for the threat factor is 1.7668 . The strength score is above the weakness score with a difference of $(+) 0.5894$, the opportunity score is above the threat score with a difference of $(+)$ 0.2905. From the results of the identification of all internal and external factors and the determination of the difference in score values, then it is described in a Cartesian SWOT diagram, where the strength and opportunity factors are given a positive value $(+)$, in addition to the weakness and threat factors are given a negative value (-). The Cartesian SWOT diagram can be seen in Figure 1. 


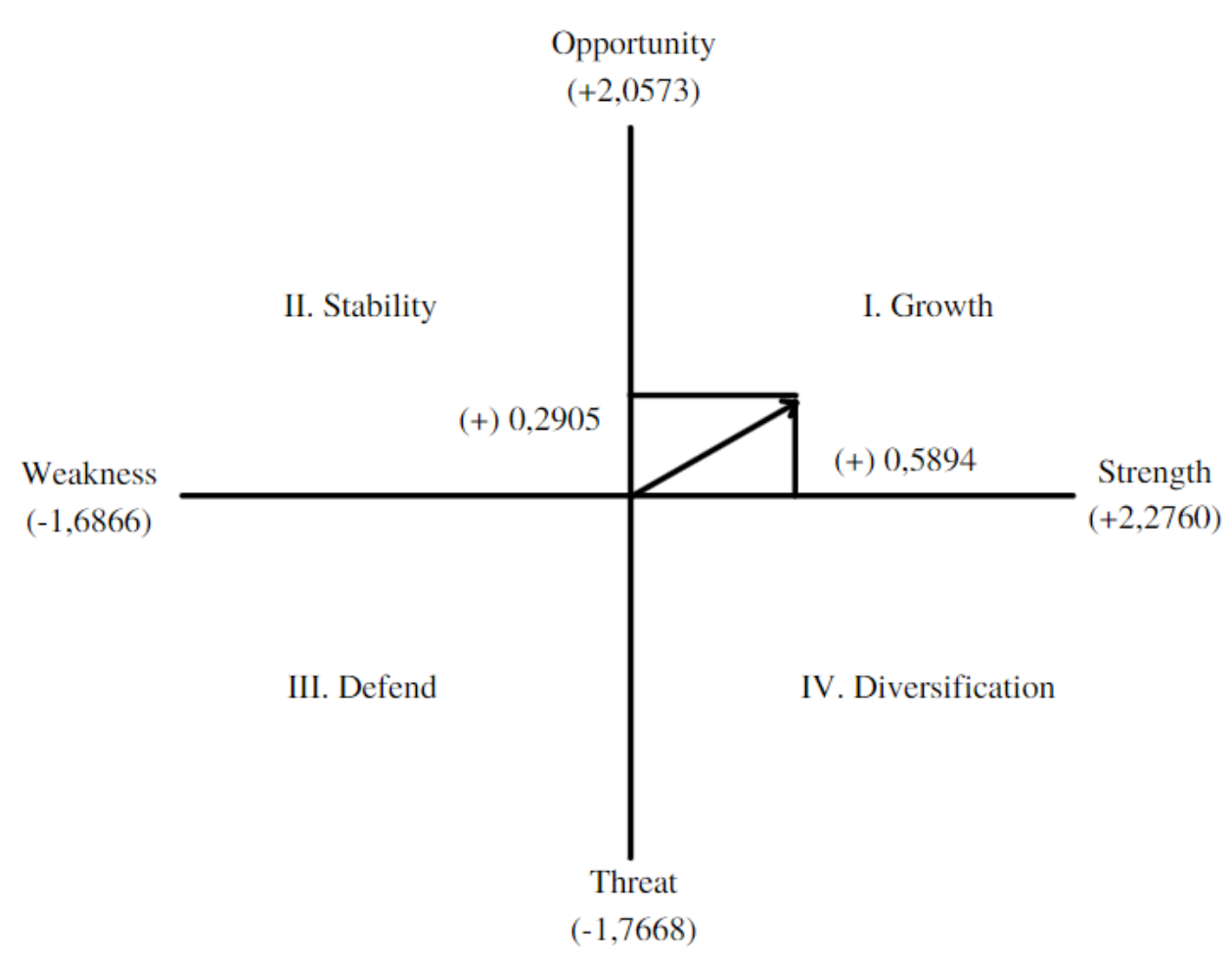

Figure. 1. SME SWOT Cartesian Diagram

Based on the Cartesian SWOT diagram in Figure 1, it can be seen that SMEs in utilizing social media as marketing are in quadrant I, which means that the strategy used is a growth strategy.

Table 3. Combination of Quantitative Strategies in SMEs

\begin{tabular}{|c|l|l|}
\hline \multirow{2}{*}{ EFAS | IFAS } & \multicolumn{1}{|c|}{ Strengths -S } & \multicolumn{1}{c|}{ Weakness -W } \\
\hline \multirow{2}{*}{ Opportunities -O } & $\begin{array}{l}\text { SO Strategy } \\
=2.2760+2.0573 \\
=4.3332\end{array}$ & $\begin{array}{l}\text { WO Strategy } \\
=1.6866+2.0573 \\
=3.7439\end{array}$ \\
\hline Threats -T & $\begin{array}{l}\text { ST Strategy } \\
=2.2760+1.7668 \\
=4.0428\end{array}$ & $\begin{array}{l}\text { WT Strategy } \\
=1.6866+1.7668 \\
=3.4535\end{array}$ \\
\hline
\end{tabular}

Based on Table 3. The combination of quantitative strategies in SMEs above shows that the largest weight score is in the S0 strategy, which is 4.3332. From the results of the Cartesian SWOT diagram analysis and the quantitative strategy combination table shows the suitability of the strategy taken, namely the SO strategy, which is a strategy that uses strength (strength) to take advantage of opportunities (opportunity) that exist in SMEs, so that the implementation of a good SME strategy in utilizing social media as marketing tools are:

- By increasing the intensity of the promotion.

- Maintain product and service quality 
- Maintain and increase customer trust

- Communicative to customers

\section{Conclusion}

Social media such as Facebook, Twitter, Instagram, Whatsapp and YouTube are now used as promotional media because social media has become a platform that consumers often use when spending their time online. SWOT analysis is to analyze the strengths, weaknesses and competitive advantages. SWOT analysis compares external opportunities and threats with internal strengths and weaknesses.

The application of the SWOT method can provide alternative recommendations for decision making. Based on the results of testing and SWOT analysis to analyze data using the IFAS SME Matrix and the SME EFAS Matrix, it produces a weighted score for each criterion. The IFAS SME Matrix, obtained the score for the strength factor is 2.2760 and the score for the weakness factor is 1.6866, and the SME EFAS Matrix, obtained the score for the opportunity factor is 2.0573 and the score for the threat factor is 1.7668 . SMEs in utilizing social media as marketing are in quadrant I, which means that the strategy used is a growth strategy. Referring to the results of the analysis, SMEs should carry out an SO strategy using social media with the intention of marketing their products or services, providing certain information to consumers and promoting the products they produce. Social media is used as a marketing communication tool to increase consumer awareness of the product, improve product image, and end up increasing sales. Based on the results of the study, suggestions that can be given by researchers are as follows:

- Further research can be further developed by conducting an analysis of the opportunities and threats of the business system that you want to develop as with the development of the internet today, it will be more advanced and modern.

- Future research is expected to have a wider range of respondents.

\section{References}

[1] Maoyan et al. 2014. "Consumer Purchase Intention Research Based on Social Media Purchase Intention Research Based on Social Media"

[2] Gunawan, D. D., dan Huarng, K. 2015. "Viral effects of social network and media on consumers' Purchase intention". Journal of Business Research, 68(11), 2237-2241.

[3] Kotler and Keller. 2016. Marketing Management. Pearson: Prentice hall

[4] Ghobakhloo, M., Sabouri, M.S., Hong, T.S., Zulkifli, N., 2011. Information Technology Adoption in Small and Medium-sized Enterprises; An appraisal of two literature. Interdisciplinary Journal of Research in Business, 1 (7), pp. 53-80.

[5] Saravanakumar, M., Lakshmi, T.S., 2012. Social Media Marketing. Life Science Journal, 9 (4), pp. 4444- 4451.

[6] Rangkuti, Freddy. (2001). Analisis SWOT Teknik Membedah Kasus Bisnis. Gramedia. Pustaka Utama.

[7] David, Fred. R. (2011). Strategic management: concepts and cases. Fred R. David._-13th ed. Francis Marion University, Florence, South Carolina

[8] Zuhrotun Nisak. 2014. Analisis SWOT untuk Menentukan Strategi . Jurnal EKBIS. Fakultas Ekonomi: Universitas Islam 
[9] Boyd, D.M., Ellison B., 2007, "Special Network Site: Definition, History,, and Scholarship", Journal of Computer-Mediated Communication, vol 13 No 1

[10] Morrison, 2007., "Periklanan Komunikasi Pemasaran terpadu”, Ramdina Perkasa, Jakarta

[11] Setiadi, N.J., 2013, "Perilaku Konsumen: Konsep dan Implikasi untuk Strategi dan Penelitian Pemasaran", Prenada Media Group, Jakarta

[12] Assauri, Sofjan, 2007,'Manajemen Pemasaran Dasar Konsep dan Strategi”, Jakarta : PT. Rajagrafindo Persada

[13] Tjiptono, Fandy dan Chandra, Gregorius, 2012. “Pemasaran Strategik Edisi Dua”, Yogyakarta : CV. Andi Offset 